\title{
Erratum to: Restoring Ecological Integrity in Highly Regulated Rivers: The Role of Baseline Data and Analytical References
}

Peter W. Downs • Maia S. Singer • Bruce K. Orr • Zooey E. Diggory $\cdot$ Tamara C. Church •

John C. Stella

Published online: 15 July 2012

(C) Springer Science+Business Media, LLC 2012

Erratum to: Environmental Management (2011) 48:847-864

DOI 10.1007/s00267-011-9736-y

During revisions to the 2011 manuscript by Downs, P.W., et al., data were incorporated from research by J.C. Stella who should have been added as a co-author.
The authorship is presented correctly here and the full citation for the article should read:

"Downs, P.W., Singer, M.S., Orr, B.K., Diggory, Z.E., Church, T.C., and Stella, J.C. (2011) Restoring ecological integrity in highly regulated rivers: the role of baseline data and analytical references. Environmental Management, 48: 847-864."

The online version of the original article can be found under doi:10.1007/s00267-011-9736-y.

P. W. Downs $(\square)$

Department of Geography, Earth \& Environmental Sciences, University of Plymouth, Drake Circus Plymouth PL4 8AA, Plymouth, UK

e-mail: peter.downs@plymouth.ac.uk

M. S. Singer · B. K. Orr · Z. E. Diggory

Stillwater Sciences, Berkeley, CA, USA

T. C. Church

Department of Landscape Architecture and Environmental

Planning, University of California, Berkeley, CA, USA

J. C. Stella

Department of Forest and Natural Resources Management, State University of New York College of Environmental Science and Forestry, One Forestry Drive, Syracuse, NY 13210, USA

e-mail: stella@esf.edu 